\title{
Two Masons Electrocuted after Contact with an Overhead Power Line
}

\section{Incident Number: 13KY010}

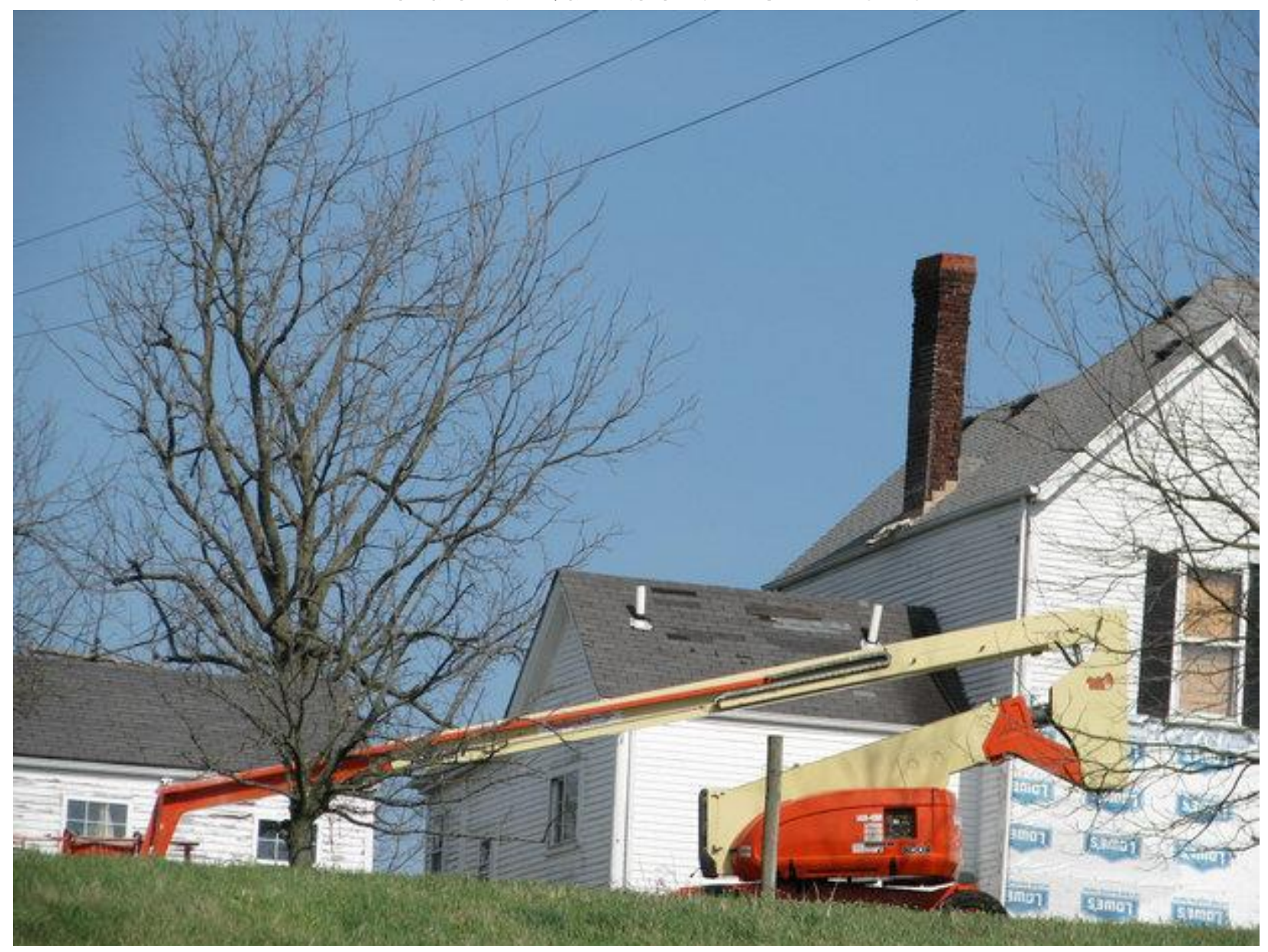

Photo courtesy of Lexington Herald Leader

Kentucky Fatality Assessment and Control Evaluation Program Kentucky Injury Prevention and Research Center 333 Waller Avenue

Suite 242

Lexington, Kentucky 40504

Phone: 859-323-2981

Fax: 859-257-3909

www.kiprc.uky.edu

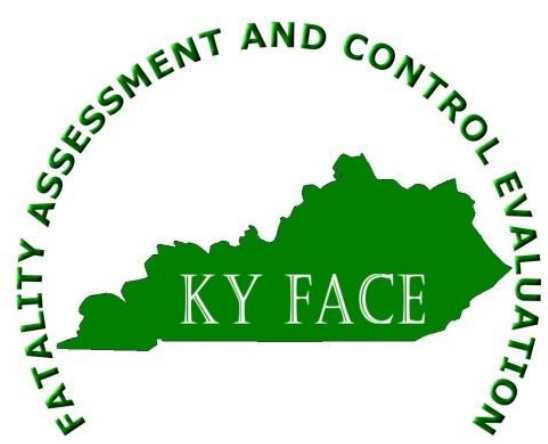




\section{Kentucky Fatality Assessment and Control Evaluation (FACE) Program Incident Number: 13KY010 Release Date: February 11, 2015 Subject: Two Masonry Workers Electrocuted after Contact with an Overhead Power Line}

\section{Summary}

On April 3, 2013, a sunny and windy spring morning, around 10:15 am, two male masons, ages 51 and 76, each an owner of his own small business, were performing repair work on a chimney of an unoccupied house in a rural area. Both masons were in the bucket of an aerial lift, which was elevated to allow them to reach the chimney. They had finished work on the chimney and were in the process of swinging the bucket around to bring it back to the ground, when the bucket came in contact with overhead power lines running behind the house. The bucket hit a 7,200 volt line and the two masons were electrocuted immediately. They were not discovered until the local electric company was notified of a power outage and sent a crew to discern the cause of the outage. More than one hour elapsed between the time of the incident and arrival of the utility workers. The utility workers arrived at approximately 11:50 am and discovered the two masons still in the elevated bucket of the aerial lift, part of which was on fire, and immediately called the fire department. The two masons were declared dead at the scene.

To prevent future occurrences of similar incidents, the following recommendations have been made:

Recommendation No. 1: Employees should conduct a jobsite survey to identify potential hazards and develop and implement appropriate control measures for the hazards.

Recommendation No. 2: Employees should follow existing OSHA regulations and safe work practices concerning the operation of equipment in close proximity to overhead power lines, and take steps necessary to de-energize or insulate power lines before work begins.

Recommendation No.3: Employees should ensure that when working near a high voltage overhead power line where visibility could be obstructed or clearances difficult to determine, an observer is used to help the operator maintain the required clearance.

Recommendation No 4: Employees should be trained in hazard recognition and the avoidance of unsafe conditions.

Recommendation No. 5: Employers should ensure that workers who operate aerial lifts are properly trained in the safe use of the equipment. 


\section{Introduction}

On Wednesday, April 3, 2013, the Kentucky Fatality Assessment and Control Evaluation program was notified by the local news channel, of an occupational incident involving two masons, a non-immigrant and an immigrant, each an owner of his own small business. The two masonry businessmen met each morning at a local coffee shop. The non-immigrant mason victim was hired by an out-of-state homeowner to repair a chimney on a long unoccupied white clapboard-sided home on a sparsely populated road at the edge of a rural county. He asked the immigrant masonry businessman if he would assist him with a job he was hired to do. Agreeing to assist him, one of the masons rented an articulating boom lift (also known as an aerial lift) to elevate them to the chimney for an extended period of time and allow them to perform the necessary repair work. At approximately 10:00 am, the two masons climbed into the aerial lift and swung the bucket striking a 7,200-volt line owned by Kentucky Utilities, and electrocuting both masons.

\section{Employer}

The Employer was a non-immigrant victim (victim \#1) who had owned his small business for 17 years. The company performed masonry work on bricks, chimneys and other freelance work. There were no other employees at the company.

\section{Written Safety Programs and Training}

There were no worker safety or training programs, since each victim owned his own company.

\section{Victims}

Victim \#1 was a 51-year-old male who owned a small masonry business and had been in business for 17 years, having learned the masonry craft from his father. He had been a mason for his entire professional career, approximately 31 years. Victim \#1 was a father of four daughters and had three grandchildren.

Victim \#2 was born in Berlin, Germany, and moved to Kentucky in 1996. He had a high school education and a wife, daughter and son who live in Europe. Victim \#2 was 75-years-old.

\section{Incident Scene}

The scene was a home located in a rural county. The home was vacant at the time of the incident. There were very few houses on the road.

\section{Weather}

On the day of the incident, the temperature ranged from 62 to 84 degrees Fahrenheit and there was no precipitation. The conditions were windy. 


\section{Investigation}

The Kentucky Fatality Assessment and Control Evaluation Program was notified of double occupational fatalities involving two male masons who were both electrocuted in the bucket of an aerial lift. Interviewed for this report were the responding sheriff's deputy and a representative of the rental company that rented them the aerial lift. A site visit was made two days after the incident and photographs were taken.

On Wednesday, April 3, 2013, a windy spring morning, two masonry workers were conducting masonry repair work on the chimney of an unoccupied house along a rural road with few houses. The masons had rented an aerial lift and were in the elevated bucket performing the repair work on the chimney. Victim \#1 had rented aerial lifts many times before. The lift was parked parallel to the rear left side of the house approximately 10 feet away from the side of the house. Shortly before 10:20 am they prepared to lower the bucket to the ground.

The masons controlled the bucket steering from inside the bucket itself and swung it away from the house to lower it back to the ground. As they swung the bucket around, the bucket came into contact with the overhead power lines that were located behind the house. There was a distance of approximately 30 feet between the back of the house and the overhead power lines. The bucket hit the 7,200 volt line and the two masons were electrocuted immediately. The power line came down, burning on the ground and knocking out power to residents in the surrounding area. The force of the electric current was so strong that the tires on the aerial lift burned and were reduced to a pile of scorched rubber. There was also a fire around the downed power line on the ground.

A resident in the area called the local utility company at 10:20 am to report a power outage. The job was assigned to a crew at 10:40 am and the crew traveled to the area of the outage. The technicians determined that a line was down and traced it back to its source at approximately 10:50. When they did, they discovered the two male masons, apparently deceased, still in the elevated bucket of the aerial lift. The crew called the local fire department because the tires of the aerial lift were on fire, as well as the ground around the downed power line. A deputy sheriff was the next to arrive on the scene, followed by the deputy coroner who declared both men dead at the scene.

\section{Cause of Death}

The cause of death for both masons was electrocution.

\section{Recommendations and Discussions}

\section{Recommendation No. 1: Employees should conduct a jobsite survey to identify potential hazards and develop and implement appropriate control measures for the hazards.}

The victims did not take the time to conduct a jobsite survey for hazards and take appropriate measures to reduce their risk. It's important this is done at each job site in order to ensure the safety of those working in that area. 
Recommendation No. 2: Employees should follow existing OSHA regulations and safe work practices concerning the operation of equipment in close proximity to overhead power lines, and take steps necessary to de-energize or insulate power lines before work begins.

All overhead power lines should always be treated as energized, regardless of whether they are down or appear to be insulated. Masons who know they are going to be working in close proximity to overhead power lines should contact the local utility company to request shut-off while work is being performed around them. If the lines cannot be shut off, the utility company can install insulation over the lines while work is being done near them. If the lines cannot be shut off or insulated, a minimum safe distance of 10 feet from the lines must be maintained. ${ }^{1}$ It may be necessary to designate a particular person to monitor activity around the lines to ensure that this safe distance is maintained at all times. ${ }^{2}$

Recommendation No. 3: Employees should ensure that when working near a high voltage overhead power line where visibility could be obstructed or clearances difficult to determine, an observer is used to help the operator maintain the required clearance.

If the two masons electrocuted in this incident had positioned an observer on the ground before they swung the bucket around to return to the ground, contact with the overhead power line may have been avoided and they could have instead safely returned to the ground.

\section{Recommendation No 4: Employees should be trained in hazard recognition and the avoidance of unsafe conditions.}

OSHA provides free worker safety training on various topics to the working public. Those who are self-employed should consider taking advantage of this free opportunity to educate themselves on various worker safety issues.

Recommendation No. 5: Employers should ensure that workers who operate aerial lifts are properly trained in the safe use of the equipment.

The two masons who were electrocuted in this incident did not own, but rather rented, the aerial lift that they used to perform the masonry work on the chimney of this house. A representative of the rental company that rented the aerial lift to one of the masons said that the one mason regularly rented aerial lifts from his company and was quite competent to use them. It is unknown how often the other mason used aerial lifts to perform masonry work or how competent he was to use this type of equipment. It is unknown whether the two masons tested the controls on the aerial lift, as is recommended, before using the equipment. The condition of the aerial lift used in this incident was not known. The rental company did not grant access to FACE staff to examine the aerial lift after the incident.

\section{Keywords}

Mason 
Aerial Lift

Electrocution

\section{References}

${ }^{1}$ OSHA Fact Sheet: Using Aerial Lifts. Occupational Safety and Health Administration. [http://www.osha.gov/OshDoc/data_Hurricane_Facts/aerial_lifts.pdf] Accessed on September $18,2014$.

${ }^{2}$ Overhead Power Line Tips for Construction Workers. Occupational Safety and Health Administration. [http://www.lni.wa.gov/Safety/Topics/AtoZ/OverheadPowerLines/training.asp] Accessed on September 19, 2014.

\section{Acknowledgements}

The Kentucky FACE program would like to thank the local sheriff's department and the equipment rental company for their assistance with this report.

The Kentucky Fatality Assessment \& Control Evaluation Program (FACE) is funded by grant 2U60OH008483-10 from the Centers for Disease Control and the National Institute for Occupational Safety and Health. The purpose of FACE is to aid in the research and prevention of occupational fatalities by evaluating events leading to, during, and after a work related fatality. Recommendations are made to help employers and employees have a safer work environment. For more information about FACE and KIPRC, please visit our website at: www.kiprc.uky.edu 